\title{
Broadband Seismic Deployments for Imaging the Upper Mantle Structure in the Lützow-Holm Bay Region, East Antarctica
}

\author{
Masaki Kanao, ${ }^{1}$ Yusuke Usui, ${ }^{2}$ Tomofumi Inoue, ${ }^{2}$ and Akira Yamada $^{2}$ \\ ${ }^{1}$ National Institute of Polar Research, Research Organization of Information and Systems, 10-3 Midori-cho, \\ Tachikawa-shi, Tokyo 190-8518, Japan \\ ${ }^{2}$ Geodynamics Research Center, Ehime University, Bunkyo-cho 2-5, Matsuyama, Ehime 790-8577, Japan
}

Correspondence should be addressed to Masaki Kanao, kanao@nipr.ac.jp

Received 16 January 2011; Revised 14 May 2011; Accepted 31 May 2011

Academic Editor: Martin Tygel

Copyright () 2011 Masaki Kanao et al. This is an open access article distributed under the Creative Commons Attribution License, which permits unrestricted use, distribution, and reproduction in any medium, provided the original work is properly cited.

\begin{abstract}
Broadband seismic deployments have been carried out in the Lützow-Holm Bay region (LHB), Dronning Maud Land, East Antarctica. The recorded teleseismic and local events are of sufficient quality to image the structure and dynamics of the crust and mantle of the terrain. Passive seismic studies by receiver functions and shear wave splitting suggest a heterogeneous upper mantle. Depth variations in topography for upper mantle discontinuities were derived from long period receiver function, indicating a shallow depth discontinuity at $660 \mathrm{~km}$ beneath the continental area of LHB. These results provide evidence of paleo upwelling of the mantle plume associated with Gondwana break-up. SKS splitting analysis anticipated a relationship between "fossil" anisotropy in lithospheric mantle and past tectonics. Moreover, active source surveys (DSSs) imaged lithospheric mantle reflections involving regional tectonic stress during Pan-African and succeeding extension regime at the break-up. By combining the active and passive source studies of the mantle structure, we propose an evolution model of LHB for constructing the present mantle structure.
\end{abstract}

\section{Introduction}

Deployments of broadband seismic arrays on the Antarctic continent have often been the ambitious dreams of dedicated Earth scientists. Existing seismic stations belonging to the Federation Digital Seismographic Network (FDSN) allow resolution of the structure beneath the Antarctic continent at a horizontal scale of $1000 \mathrm{~km}$, which is sufficient to detect fundamental differences in the lithosphere beneath East and West Antarctica, but not to clearly define the structure within each sector. In addition, seismicity around the Antarctic region is limited by sparse station distribution, and the detection level for earthquakes remains inadequate for full evaluation of tectonic activity [2]. A strategy of attaining a sufficient density of seismic stations on the Antarctic continent will allow for optimal ray path coverage across Antarctica and improvement of seismic tomography resolution [3-5].

Polar field deployments have been carried out in the past decades around several regions withinin the continental margins of Antarctica [6-9] including the "TransAntarctic Mountain SEISmic experiment (TAMSEIS; $[10,11])$."
Discussions at the working group of the Antarctic Neotectonics program (ANTEC) under the Science Committee on Antarctic Research (SCAR) (Siena, Italy, 2001) and the workshop on the "Structure and Evolution of the Antarctic Plate (SEAP)" (Boulder, Colorado, 2003) have led to Antarctic seismic array deployments. The principle ideas of the Antarctic arrays were derived from components of the "Regional Leapfrogging Arrays (RLA)" and the "Program Oriented Experiments (POE)".

The resultant seismic stations in Antarctica were installed as a part of several international programs initiated during the International Polar Year (IPY 2007-2008; http://classic .ipy.org/; Figure 1). Followed by the successful TAMSEIS deployment held in 2000-2002, several big geoscience projects were contacted regarding a collaborative effort to reach the interior of the Antarctic continent and surrounding region. The "Antarctica's GAmburtsev Province (AGAP; http://www.ldeo.columbia.edu/ mstuding/AGAP/)", the "GAmburtsev Mountain SEISmic experiment (GAMSEIS; http://epsc.wustl.edu/seismology/GAMSEIS/, [12, 13])" under AGAP, as well as the "Polar Earth Observing Network (POLENET; http://www.polenet.org/)" were major contrib- 


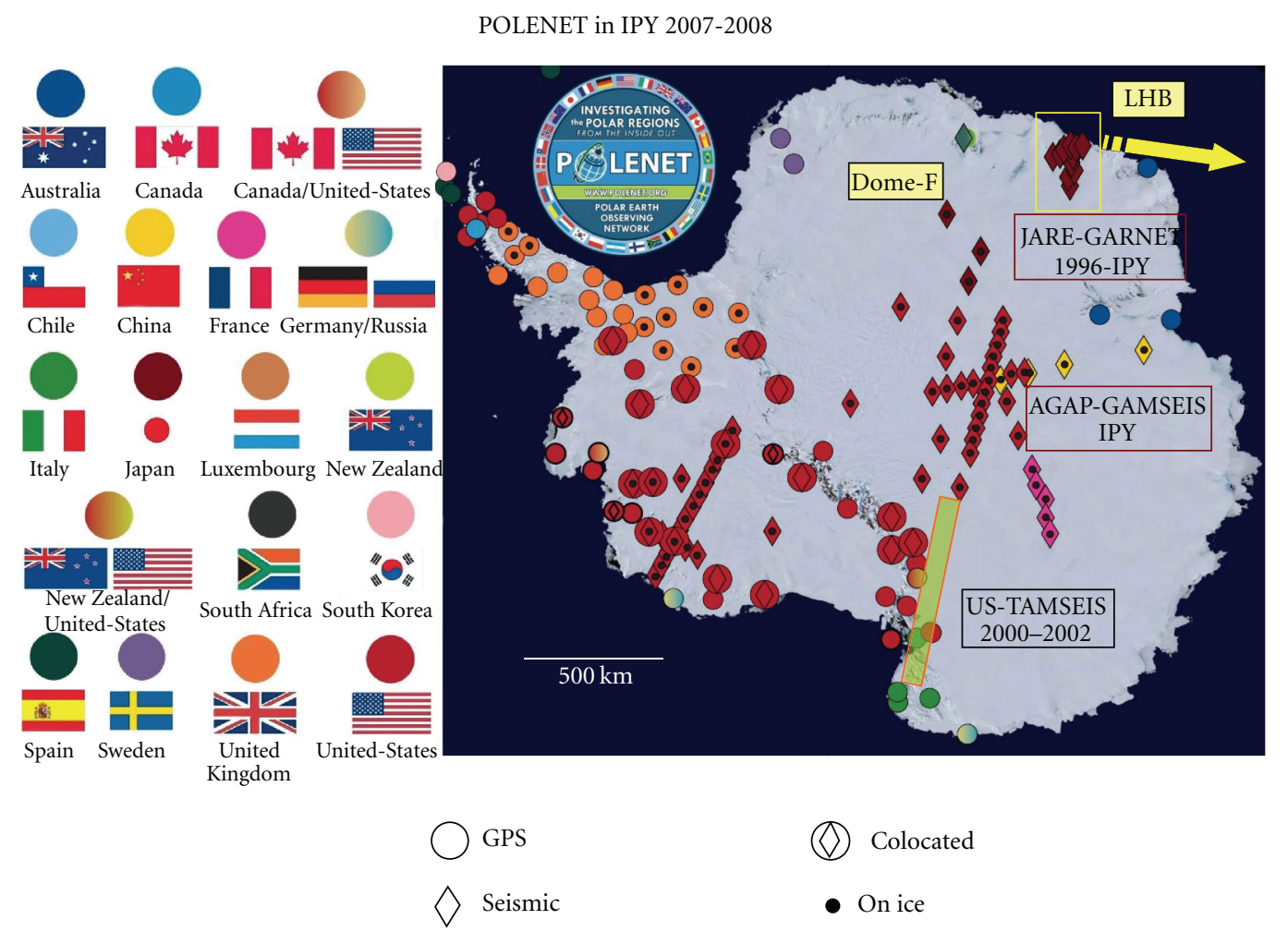

FIGURE 1: Distribution map of seismic and the other geophysical stations planned for deployed during IPY 2007-2008. The GARNET-JARE project regions are shown, as well as those of AGAP/GAMSEIS and TAMSEIS. All stations in Antarctica contribute to the POLENET program in the bipolar region. The LHB map is extended in Figure 2.

utors in establishing a geophysical network inside the Antarctic continent during the IPY.

Similar to other regions in Antarctica, monitoring observations have been conducted in the last decade by the Japanese Antarctic Research Expedition (JARE) around the Lützow-Holm Bay region (hereafter LHB), Dronning Maud Land (Figure 1). The obtained seismic data are utilized to clarify the heterogeneous structure of the Earth, particularly around the Antarctic region. Seismic deployments can efficiently study the crust and upper mantle, as well as the Earth's deep interior, including features such as the Core-MantleBoundary $(\mathrm{CMB})$ and the lowermost mantle layer $\left(\mathrm{D}^{\prime \prime}\right.$ zone) $[14,15]$. The broadband arrays in LHB make a significant contribution not only to the permanent global network of FDSN, but also to such projects as the Global Alliance of Regional Networks (GARNET), RLA, POE, POLENET, and IPY.

In this paper, data from broadband seismological studies are reviewed in order to provide clear images of the upper mantle structure and dynamics beneath LHB. By combining the passive and active source results, a regional evolution model of LHB is presented to explain the formation of the present mantle structure. Regional tectonic history such as the Pan-African orogenic event, together with the break-up process of Gondwana supercontinent in mid-Mesozoic age, could be the plausible cause of present upper mantle structure. The multidisciplinary seismic investigations reviewed in this paper supply fruitful information for understanding the regional tectonic evolution of this area.

\section{Broadband Deployments in LHB}

Broadband seismic deployments in LHB have been carried out since 1996 until present, including deployment during IPY 2007-2008 as one of the major contributions to GARNET. The stations were established on the outcrops and ice sheet around the continental margins of LHB (Figure 2). Seismic array response functions were calculated in dominant frequency of $0.03 \mathrm{~Hz}$ and $0.1 \mathrm{~Hz}$ for receiver space distribution of all the GARNET stations (Figure 3). It is expected that both the short period body waves and long period surface waves are detected and space resolution from the analyses by using the detected waveform data could evaluate the area. Except for power supply failure of some stations during winter seasons, observations have been conducted fairly well and a significant number of events were recorded of global earthquakes, local earthquakes, as well as ice-related events within close proximity to the stations (Figure 4). During the IPY period, a total number of seven stations (TOT, LNG, SKV, SKL, S16, RDV, and BTN) were continuously operated. The last three stations (S16, RDV, and BTN) were started simultaneously at the beginning of the IPY. 
Broadband stations in LHB (JARE-GARNET)

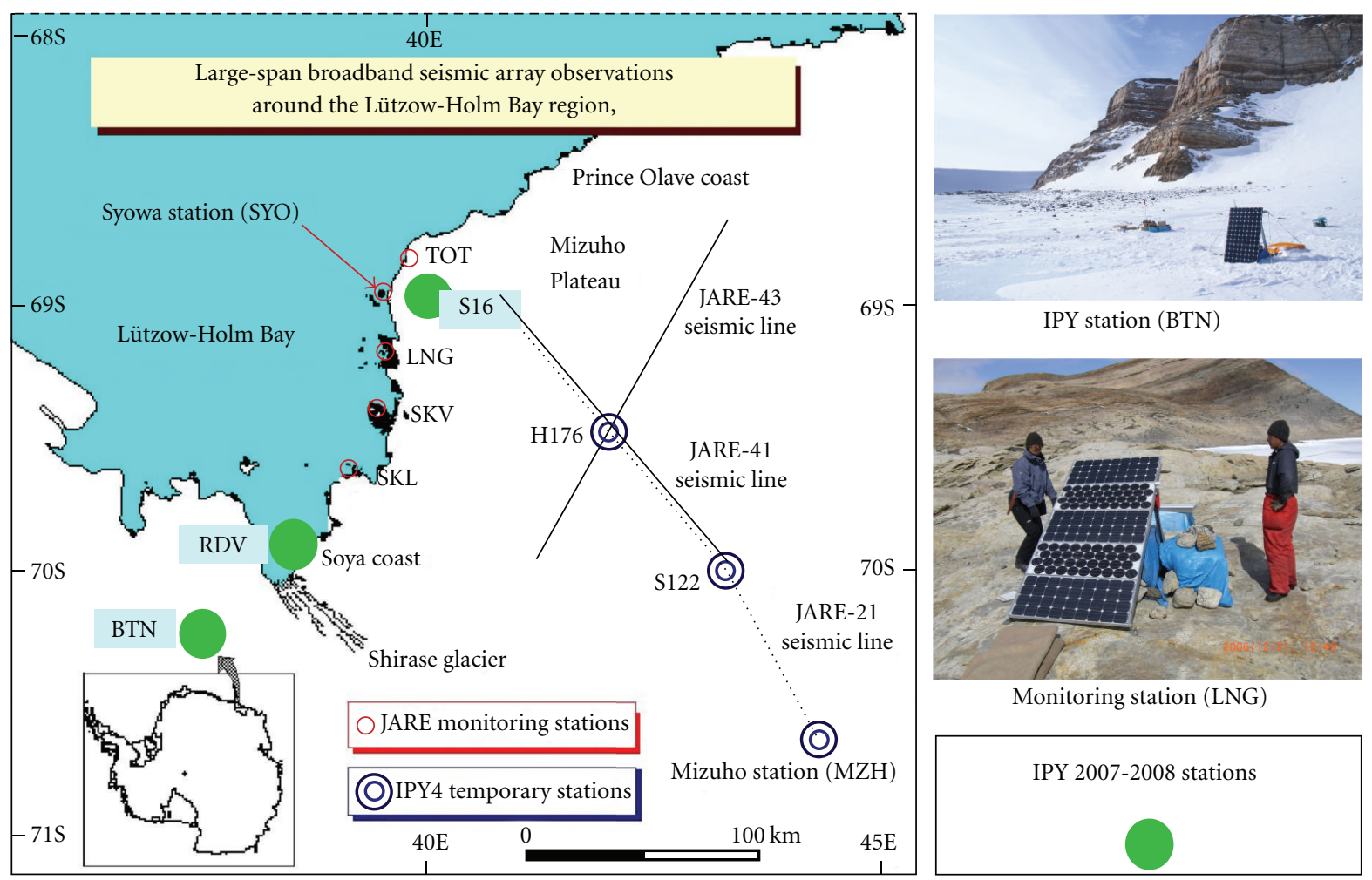

FIGURE 2: Broadband seismic stations in LHB including IPY period. Monitoring stations (red open circles), IPY stations (green solid circles), and future planned stations (blue double-open circles) are indicated, respectively.

The observation systems consisted of a portable broadband seismometer and a data-recorder (type LS8000-WD, -XT by Hakusan Co.), combined with lead-acid and solar batteries. The CMG-40T portable seismometers (Guralp System LTD.) were used with a three-component velocityresponse (flat frequency response for velocity in $0.05-10 \mathrm{~Hz}$ ). The velocity signal was digitized at a sampling frequency of $10-100 \mathrm{~Hz}$ with a dynamic range of $90 \mathrm{~dB}$ (16 bits), and stored in a hard-disk (2GB) or compact flash (CF) card (10 GB). Total solar panel power was $250-270 \mathrm{~W}$ with $12 \mathrm{~V}$ DC output, and the capacity of the lead batteries was more than $500 \mathrm{Ah}$ for each station. The systems operated continuously except in very dark and cold periods during Antarctic winters. Details of the observation systems in the first few years were described in $[19,20]$. More detailed information for the GARNET stations in LHB and operational details are available from the website of the National Institute of Polar Research (NIPR) (http://polaris.nipr.ac.jp/ pseis/garnet/).

The GARNET data are initially stored and accessible to cooperative researchers through the data library server of NIPR (POLARIS; http://polaris.nipr.ac.jp/ pseis/garnet/). After a defined period, the data are made available to world data centers of seismology, such as Incorporated Research Institute of Seismology/Data Management System (IRIS/DMS). The global data centers provide data to seismologists studying the polar regions, the Standing Committee on Antarctic Data Management (SCADM) under the Scientific
Committee on Antarctic Research (SCAR), as well as the Antarctic Master Directory (AMD) in the Global Change Master Directory (GCMD) of NASA.

During the IPY, broadband seismic deployments in LHB were conducted under the endorsed JARE project. By combining with the other big IPY projects such as the AGAP/GAMSEIS [13], moreover, the deployments in LHB could provide constraints on the origin of the Gamburtsev Subglacial Mountains in terms of understanding the broader structure of Antarctic Pre-Cambrian craton and the subglacial environment. Detection of seismic signals from basal sliding of the ice sheet and ice streams $[10,21]$ would be expected from the future study, as well as the detection of outburst floods from subglacial lakes.

\section{Seismic Velocity Discontinuities}

Interesting seismic evidence related to the structure and dynamics of LHB was obtained in the last decade by JARE geoscientific activities. The recorded teleseismic data in LHB are of sufficient quality for usage of various analyses to clarify the heterogeneous features of the Antarctic lithosphereasthenosphere system, as well as deep interiors $[5,14,15$, 22-24]. In recent years, moreover, glacial-related seismic events were detected by the LHB array stations $[25,26]$. Seismic signals involving ice-related phenomena, also known as "ice-quakes (ice-shocks)", have been associated with 


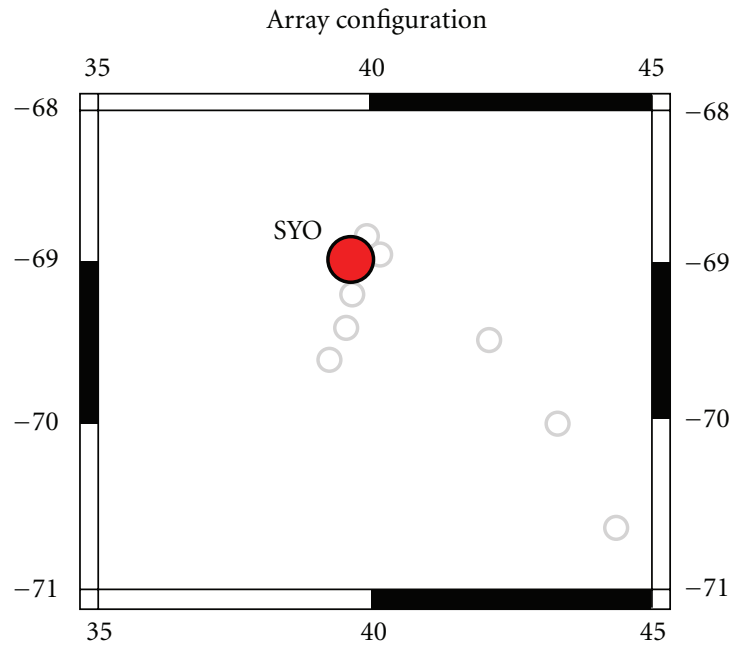

(a)

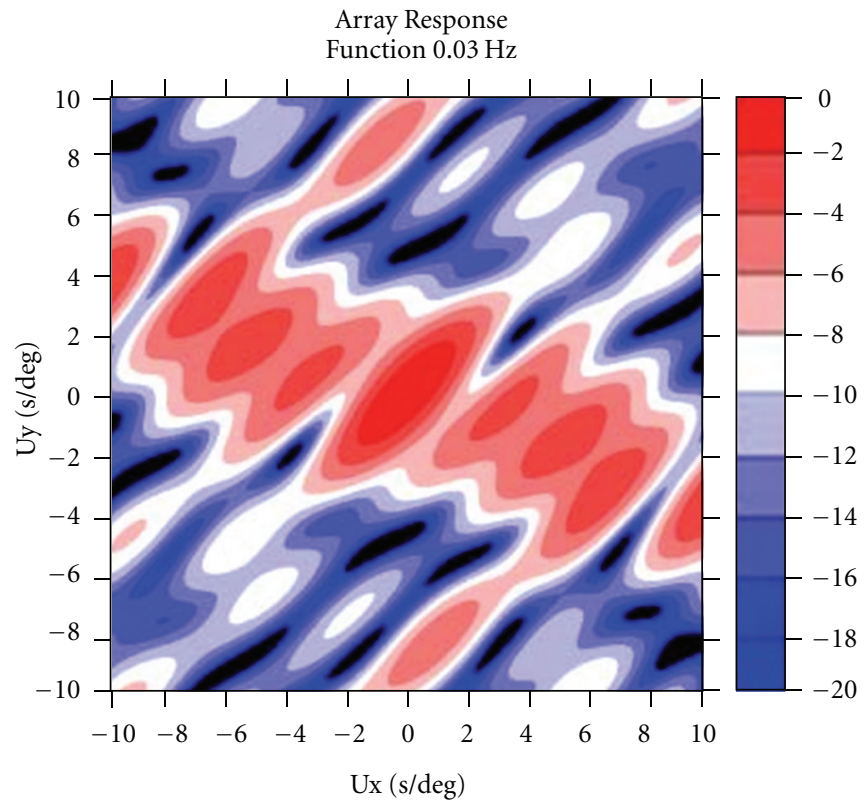

(c)

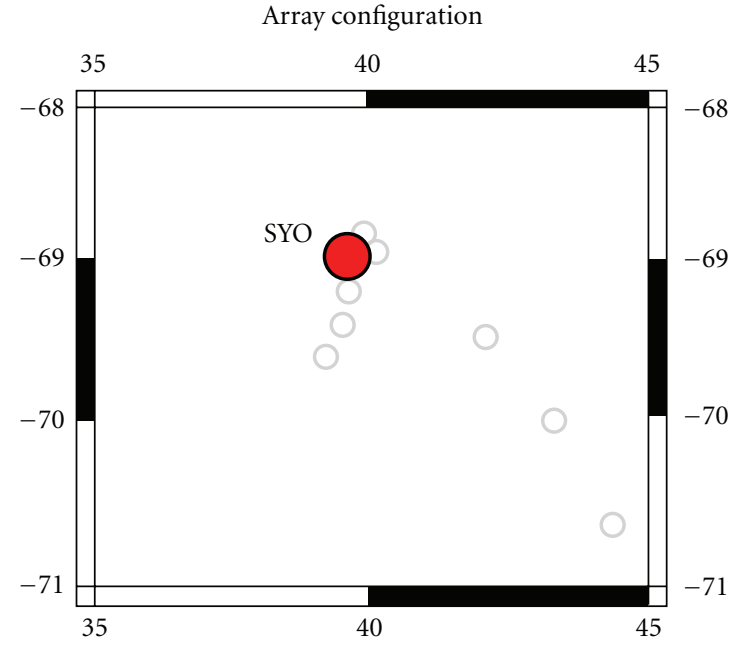

(b)

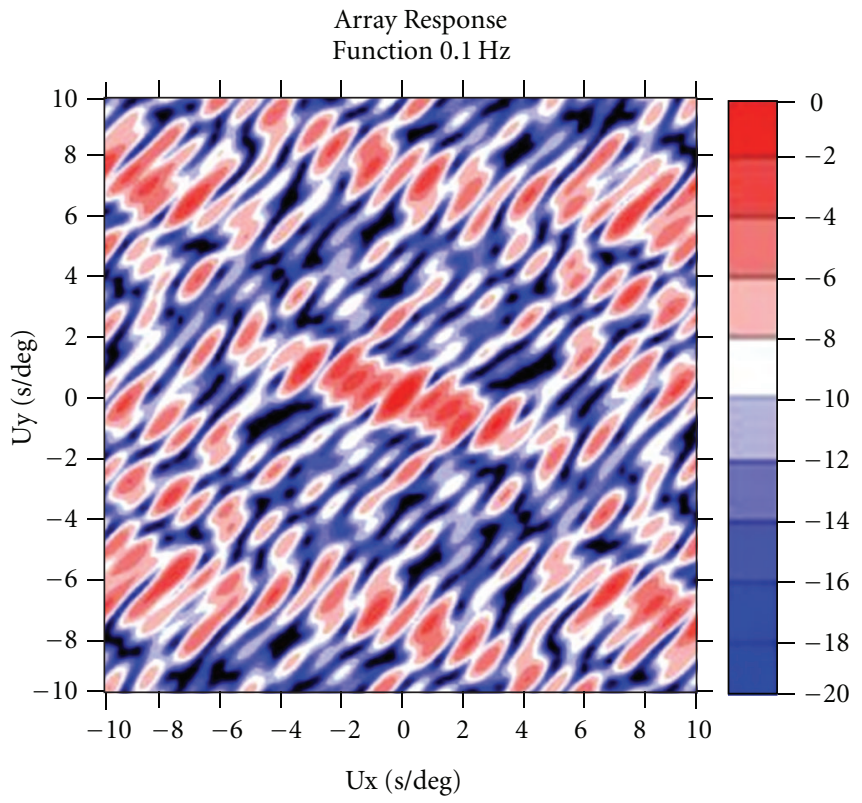

(d)

FIGURE 3: Simulated seismic array response functions in dominant frequency of $0.03 \mathrm{~Hz}$ and $0.1 \mathrm{~Hz}$ for receiver distribution for all GARNET stations as shown in Figure 2.

glacially related mass movements of ice-sheets, sea-ice, tidecracks and icebergs in the polar areas [10,25]. Despite the development of local networks in the last two decades, we can hardly distinguish a difference between waveforms by local tectonic earthquakes and those of ice-related phenomena (e.g., the unknown X-phases reported by [26]). The icerelated signals can provide unique information for local impact on Antarctic region involving global climate change.

The recorded waveforms are of sufficient quality to analyze the crust-upper mantle structure and tectonic evolution of the region. Passive seismic source studies of receiver functions, shear wave splitting, and surface wave tomography were carried out by using the data recorded from systems located on outcrops in LHB. Shear wave velocity models were inverted by fitting synthetic receiver functions to the observed data in short-period ranges. The obtained model investigated from azimuthal variations of the receiver functions represents a slightly dipping crustmantle boundary toward the coast [27]. Moreover, a gradual thickened structure of the crust in LHB was identified from the north toward the south [28]. Variations in crustal thickness along the coast may reflect the tectonic history, with increasing metamorphic grade in crystalline crust towards the south in LHB [29].

The long period receiver functions reveal depth variations in seismic discontinuities of the upper mantle (for $410 \mathrm{~km}$ and $660 \mathrm{~km}$ ) beneath the LHB [1]. Long period receiver functions (after $0.2 \mathrm{~Hz}$ low-pass filter) were 


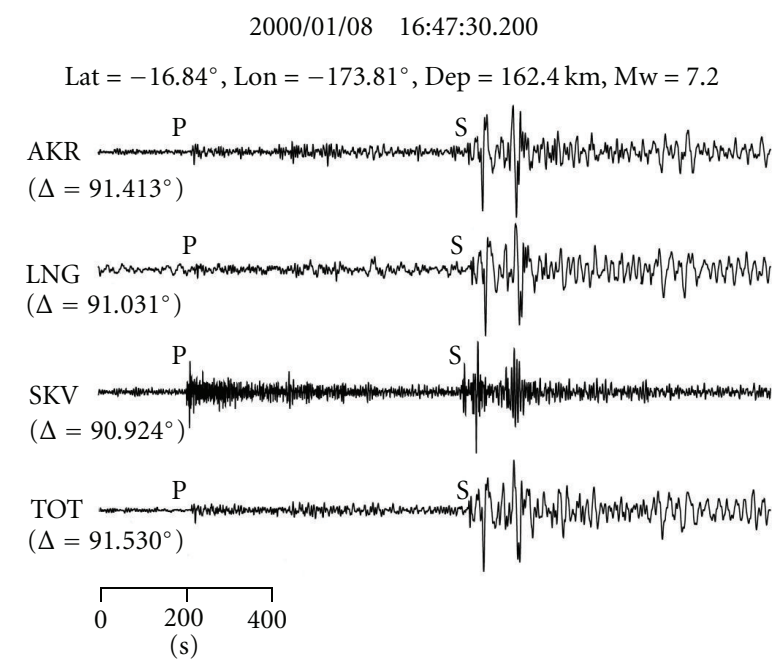

FIgURE 4: Example of the teleseismic waveforms (Fiji Island region) recorded at the GARNET stations deployed at LHB.

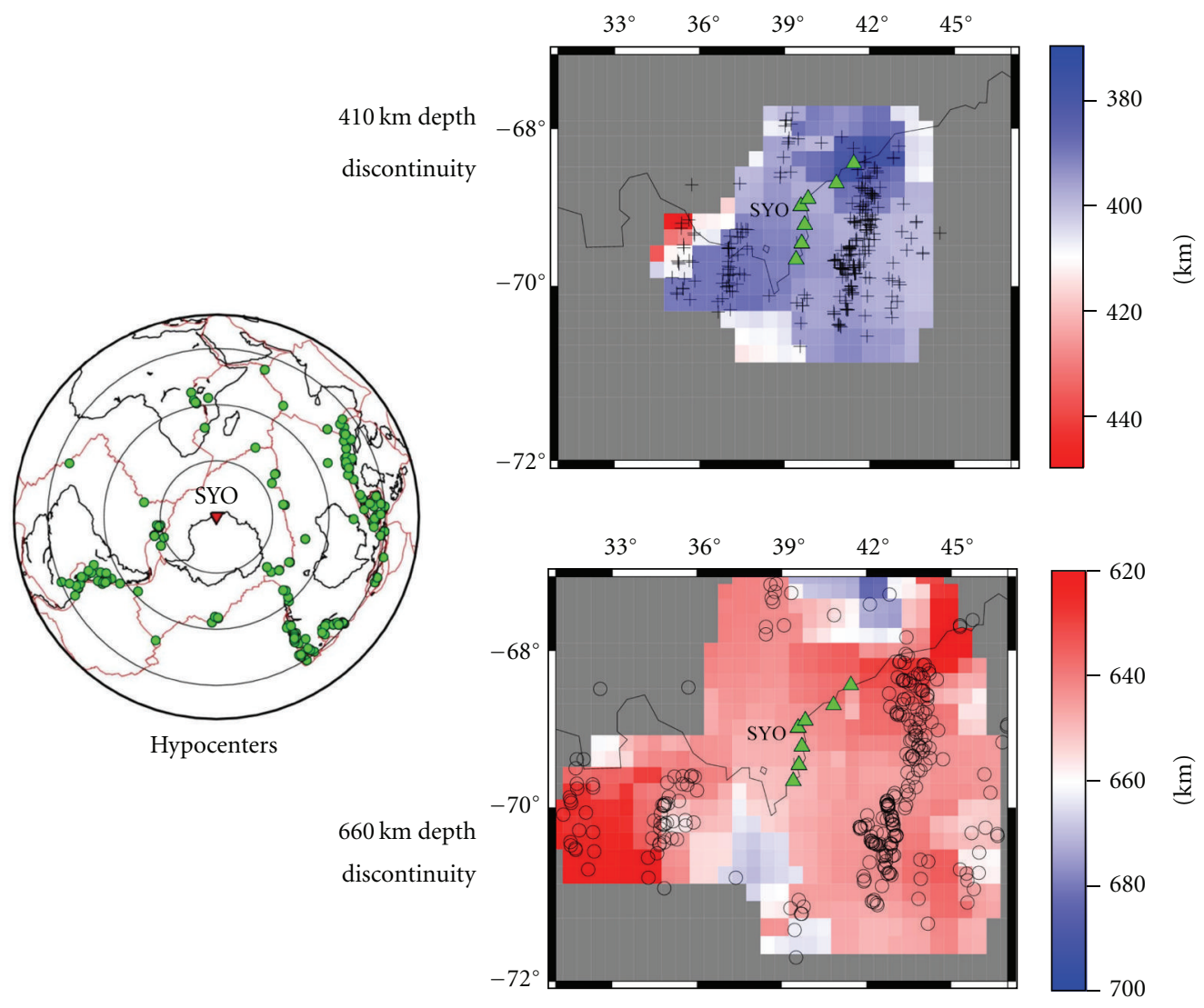

FIGURE 5: (left) Distribution of hypocenters of teleseismic events used for long-period receiver function analysis (solid circles) and SYO stations (solid triangles). (right) Distribution of P-S conversion depth points for $410 \mathrm{~km}$ (upper, crosses) and $660 \mathrm{~km}$ discontinuity (lower, open circles), respectively. Location of the conversion depth points was obtained by combining GARNET station positions in LHB and hypocenters of the utilized teleseismic events. Topographic depth variations of the upper mantle discontinuities are presented by the color contours (modified after Kanao et al. 2007 [1]). 


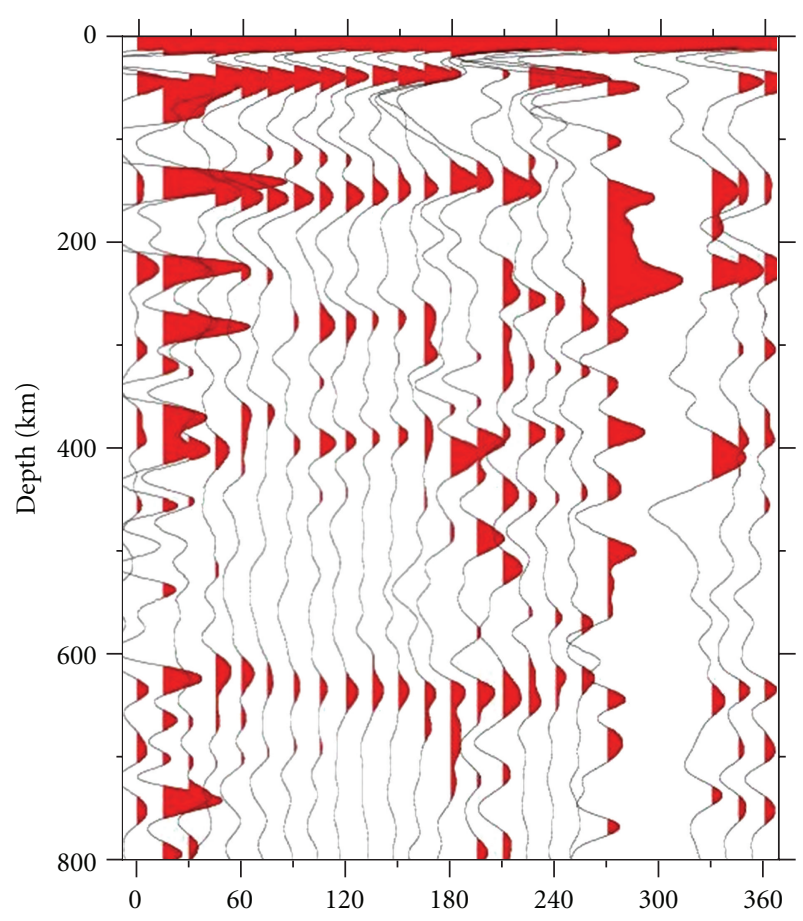

(a)

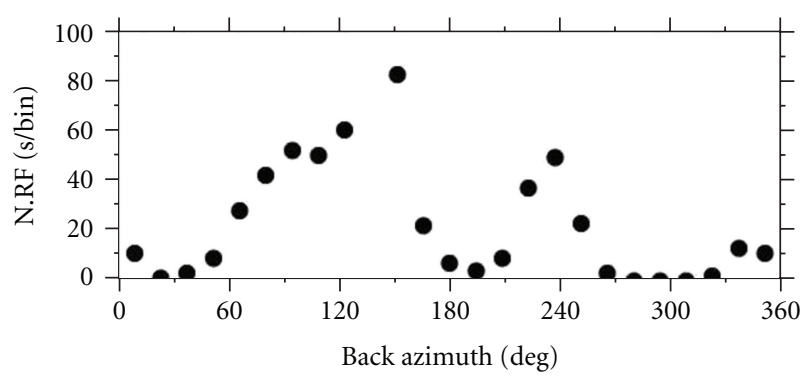

(b)

Figure 6: (a) Back azimuth distribution for the depth converted receiver functions in the upper mantle compiled for all the GARNET stations. The number of receiver functions for each 15 azimuth range is shown in (b). The back azimuths are represented from Syowa Station (SYO) against the depth conversion points calculated for all the hypocenter-station pairs.

generated using 62 teleseismic events recorded by the local broadband arrays (Figure 5, left). Variations in depth distribution of P-S conversion points were identified particularly about the $660 \mathrm{~km}$ discontinuity (Figure 5, right). Shallow depths in topography for the $660 \mathrm{~km}$ discontinuity were found beneath the continental ice sheet area, that is, SE part from the GARNET stations along the coast. The evidence might reflect the paleo upwelling of the mantle plume associated with supercontinent break-up in Mid-Mesozoic age.

Back azimuth distribution for depth-converted receiver functions was compiled for all the GARNET stations (Figure 6). The back azimuths were defined as directions of depth conversion points calculated for all the hypocenter-station pairs from Syowa Station (SYO) as a center. Back azimuth distribution for the depth variations in the upper mantle discontinuities was compiled for all stations (Figure 7). The color contours in Figure 6 indicate the smoothed amplitudes of the receiver functions. The heterogeneities were observed in both 410 and $660 \mathrm{~km}$ discontinuities in both azimuth ranges of $20-50^{\circ}$ and $200-$ $260^{\circ}$. The two back azimuth groups are almost parallel with the coast and may indicate the relationship with the break-up process of Gondwana. The evidence of break-up supported by other studies from teleseismic shear wave anisotropy and reflection imaging by active sources is shown in the succeeding chapter.

\section{Upper Mantle Anisotropy}

Seismic wave anisotropy provides information on recent and/or fossil mantle flows reflecting tectonic evolution of the study region. The seismic anisotropy in the upper mantle of LHB was derived from SKS splitting analysis for teleseismic events recorded on the GARNET stations (Figure 8; [16]). Averaged delay times of SKS wave splitting for all analyzed stations were obtained as $1.3 \mathrm{~s}$, which were almost equal to the global average. A two-layer model was assumed to model the upper mantle anisotropy; the upper layer is generally considered to correspond to the "lithosphere" and the lower layer to the "asthenosphere". For six stations in LHB, we can recognize the azimuthal variation of the splitting parameters (Figure 9).

The fast polarization directions of SKS waves were compared with the directions of Absolute Plate Motion (APM), which reflects recent mantle flow [30]. The directions of $\mathrm{APM}$ around $\mathrm{LHB}$ are about $\mathrm{N} 145^{\circ} \mathrm{E}$, and the velocity is about $1.1 \mathrm{~cm} / \mathrm{yr}$ based on the HS3-NUVEL1 model [31] (Figure 10). Since the fast polarization directions of the lower layer were generally parallel to the directions of APM, it was considered that the lower layer anisotropy reflected asthenospheric anomalies due to the horizontal mantle flow along the APM.

In contrast, the fast polarization directions of the upper layers never coincide with the APM direction (the difference is up to $100^{\circ}$ ). We offer an idea that the anisotropic structure could be involved with past tectonic events and the origin of anisotropy is "frozen" in the lithosphere. Gondwana assembly in Early Paleozoic was one of the major events in LHB [32]. The LHB experienced regional high-grade metamorphism during the Pan-African orogeny [33]. The metamorphic grade increases progressively from north to south along the coast and the maximum thermal axis lies in the southernmost part of LHB [34].

A "fossil" anisotropy in the lithospheric mantle can be estimated as caused by the past regional tectonics. The majority of the fast polarization directions in the upper layer, corresponding to the "lithosphere", were orientated in an NE-SW direction (Figure 10). This is consistent with the direction of the paleo compression stress during the Pan-African age and the conversion stage between East and West Gondwana supraterrains. We proposed that the mantle anisotropy was created by lithological orientation of mantle minerals during the amalgamation process of Gondwana, rather than in current asthenospheric flow parallel to APM. 


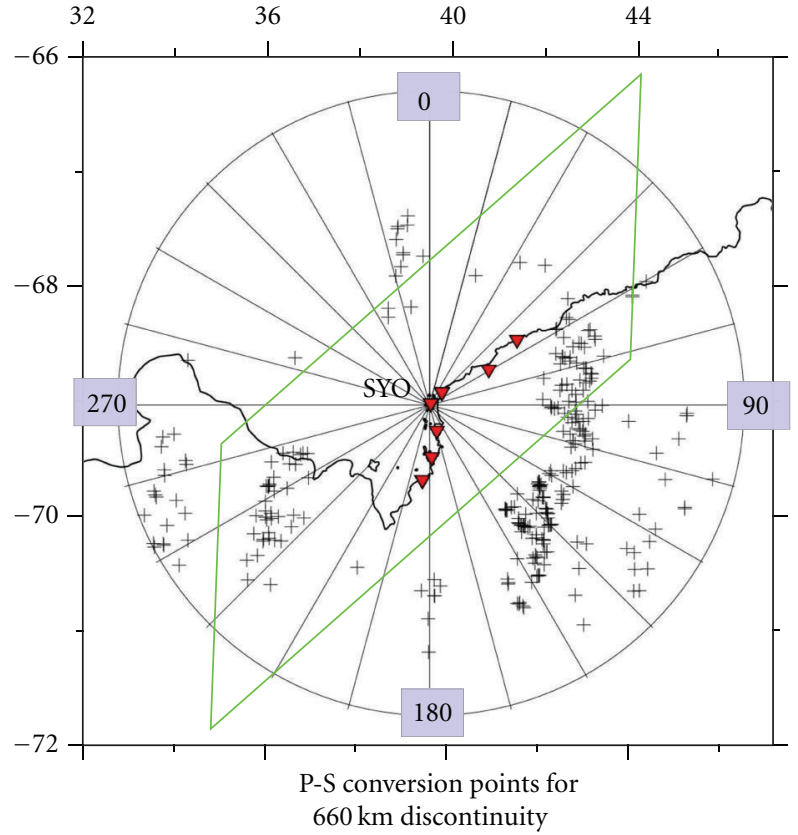

(a)

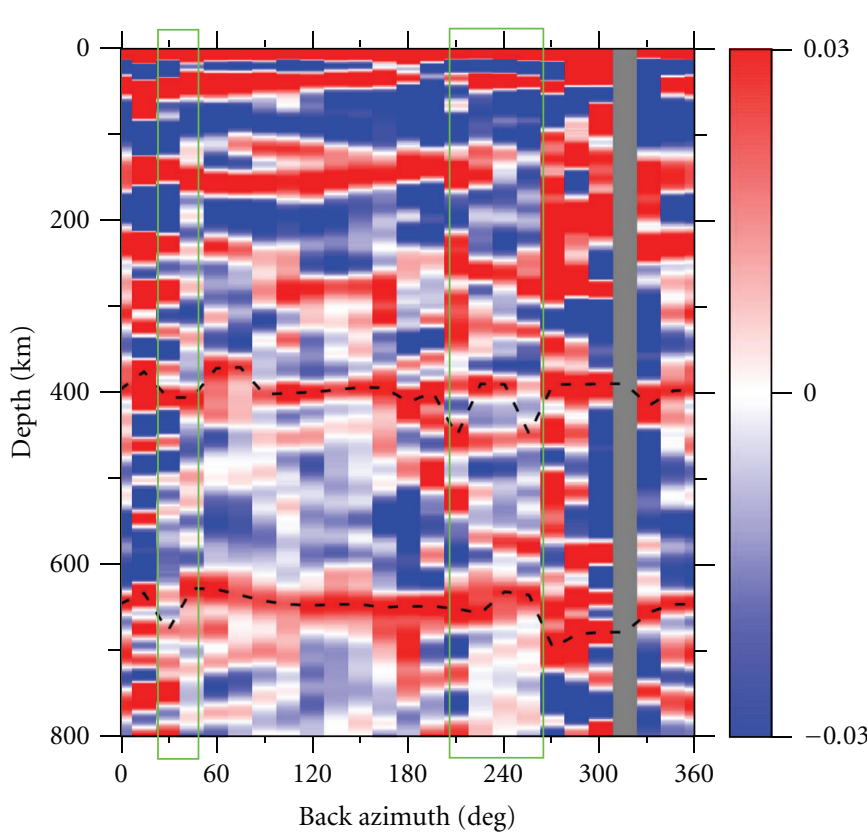

(b)

FIGURE 7: (a) Back azimuth distribution for depth variation in upper mantle discontinuities by receiver function analyses for all GARNET stations. Color images represent the smoothed amplitudes of the receiver functions shown in Figure 6. Two dashed lines are traced for the maximum amplitudes of both $410 \mathrm{~km}$ and $660 \mathrm{~km}$ depth discontinuities. The two back azimuth groups for strong depth variations in upper mantle discontinuities are circled by the light green open squares. (b) Location of the strong heterogeneous azimuths in LHB. The area for strong depth variations in upper mantle discontinuities is represented by the light green open squares, which are almost parallel with the coastal line. Symbolic notation for the P-S conversion points at the mantle discontinuities are the same as in Figure 5.

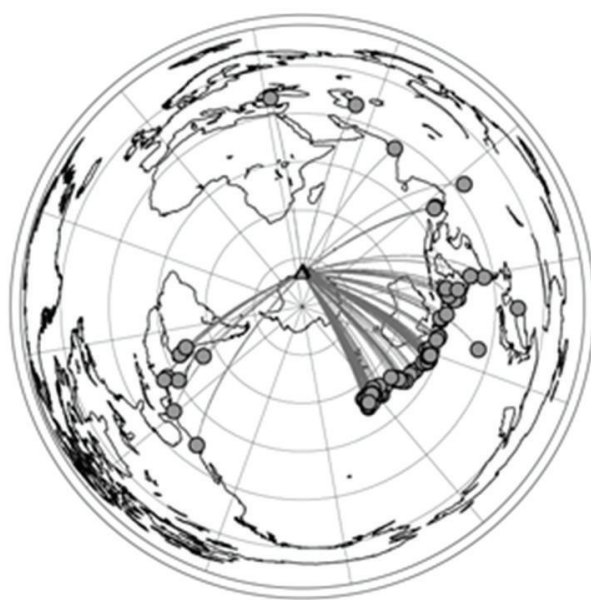

(a)

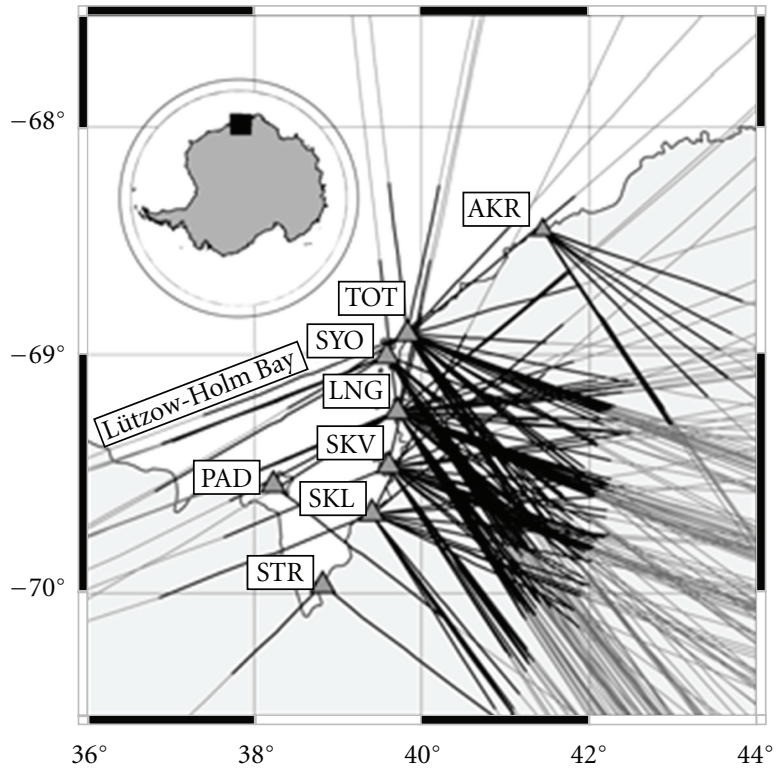

(b)

Figure 8: (upper) The global distribution of teleseismic events (solid circles) and used stations in LHB for SKS analysis (triangles). Gray lines are the ray paths from the sources. (lower) Map of the study area in LHB showing the seismic stations (triangles). Gray lines indicate SKS wave paths, and black lines indicate wave paths above $410 \mathrm{~km}$ depth. All the figures are after Usui et al. [16]. 

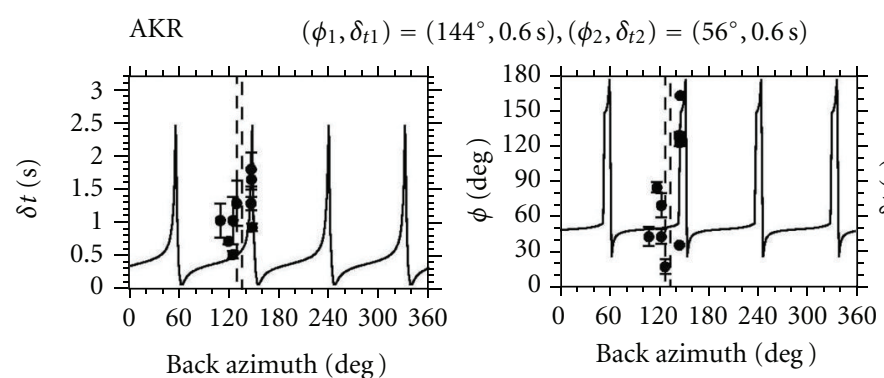

LNG

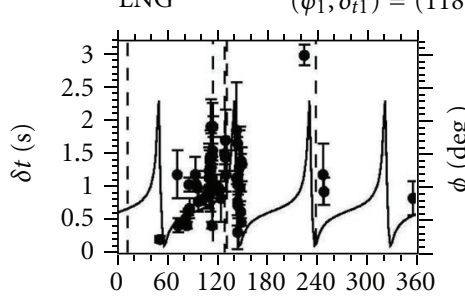

Back azimuth (deg)
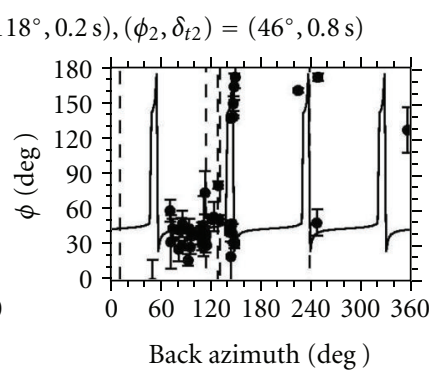

SKL

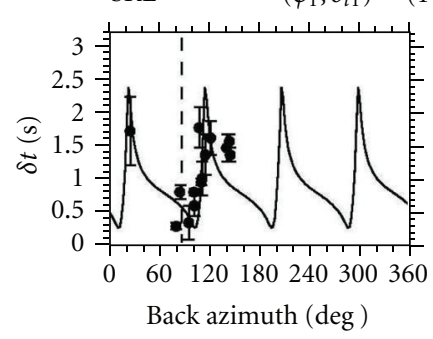

PAD
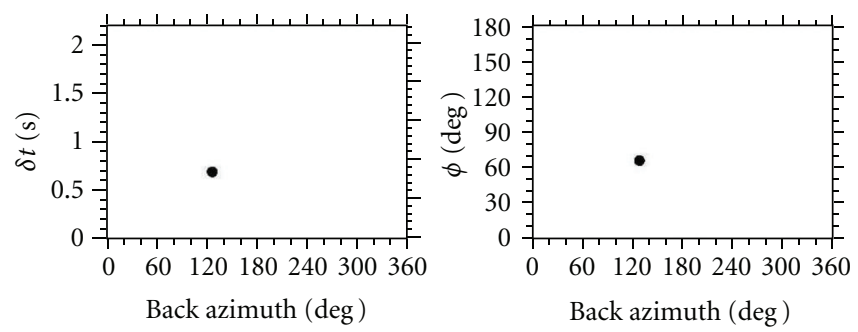

SKV

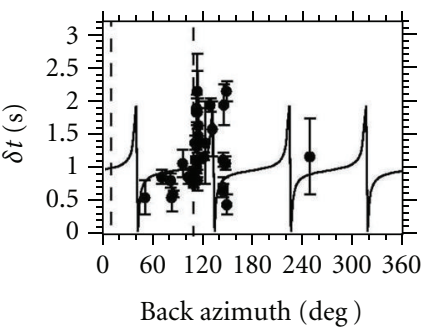

$\left(\phi_{1}, \delta_{t 1}\right)=\left(48^{\circ}, 0.3 \mathrm{~s}\right),\left(\phi_{2}, \delta_{t 2}\right)=\left(40^{\circ}, 0.7 \mathrm{~s}\right)$

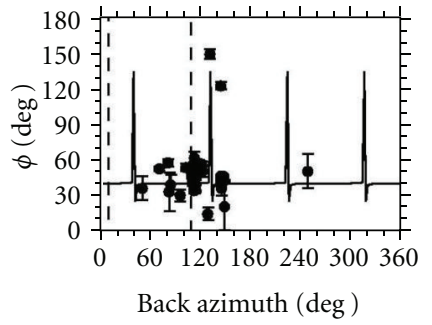

SYO $\quad\left(\phi_{1}, \delta_{t 1}\right)=\left(145^{\circ}, 0.4 \mathrm{~s}\right),\left(\phi_{2}, \delta_{t 2}\right)=\left(57^{\circ}, 1.3 \mathrm{~s}\right)$

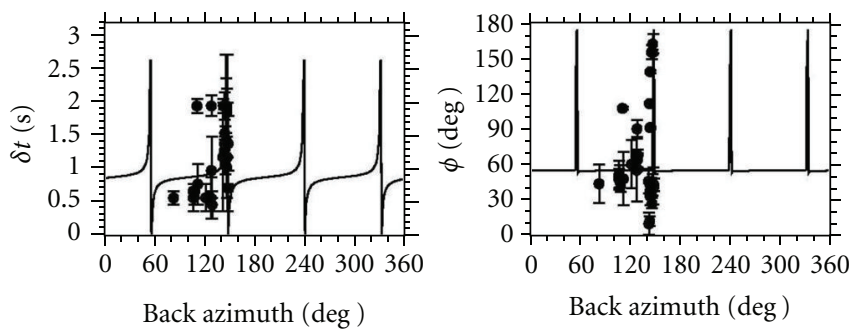

TOT

$\left(\phi_{1}, \delta_{t 1}\right)=\left(120^{\circ}, 0.2 \mathrm{~s}\right),\left(\phi_{2}, \delta_{t 2}\right)=\left(48^{\circ}, 1 \mathrm{~s}\right)$
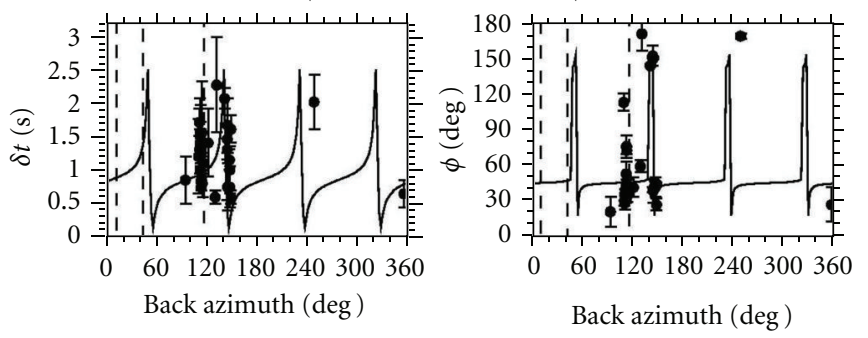

STR

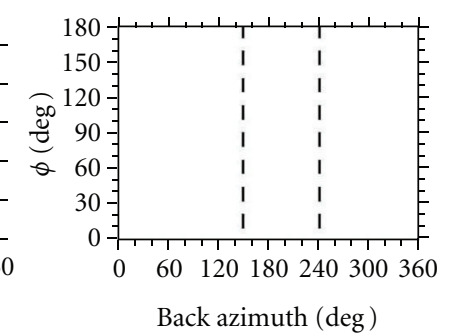

FIGURE 9: Splitting parameters of $\phi$ and $\delta t$ plotted as a function of back azimuth. Vertical dashed lines are the direction of null measurements. At stations for AKR, LNG, SKL, SKV, SYO, and TOT, the azimuthal variations of apparent splitting parameters are modeled by a two-layer case of anisotropy. The parameter pair $\left(\phi_{1}, \delta t_{1}\right)$ describes the lower layer anisotropy and $\left(\phi_{2}, \delta t_{2}\right)$ corresponds to the upper layer. All the figures are after Usui et al. [16].

\section{Seismic Reflection Imaging}

Besides the broadband passive studies, deep crust and upper mantle in LHB were investigated by active source studies (the Deep Seismic Surveys; DSS) by JARE [35-37] (Figure 11). DSS was conducted on the continental ice sheet of LHB in austral summers in 2000 and 2002 as one of the "Structure and Evolution of the East Antarctic Lithosphere (SEAL)" program. The deployments required significant logistical efforts, including the explosion of large dynamite shots along the seismic profiles on the ice sheet plateau in LHB.

Sophisticated DSS processing demonstrated pronounced reflection images of the crust-upper mantle boundary
(Moho discontinuity) and of the lithospheric mantle structure $[17,38]$. A laminated layering around the crust-mantle boundary was well imaged using coherency enhancement processing after the Normal Move Out (NMO) corrections applied to far-offset data of the SEAL-2000, -2002 profiles. For the SEAL-2000 profile, the single coverage CDP section with only far offset shots was shown in the upper part of Figure 12(a) and the single coverage CDP only with nearer traces could be identified in the lower part. Figure 12(b) shows a single-fold CDP section using only far offset shots for the SEAL-2002 profile (upper), and the CDP stack section with offsets less than $120 \mathrm{~km}$ is depicted for the same profile (lower), respectively. 


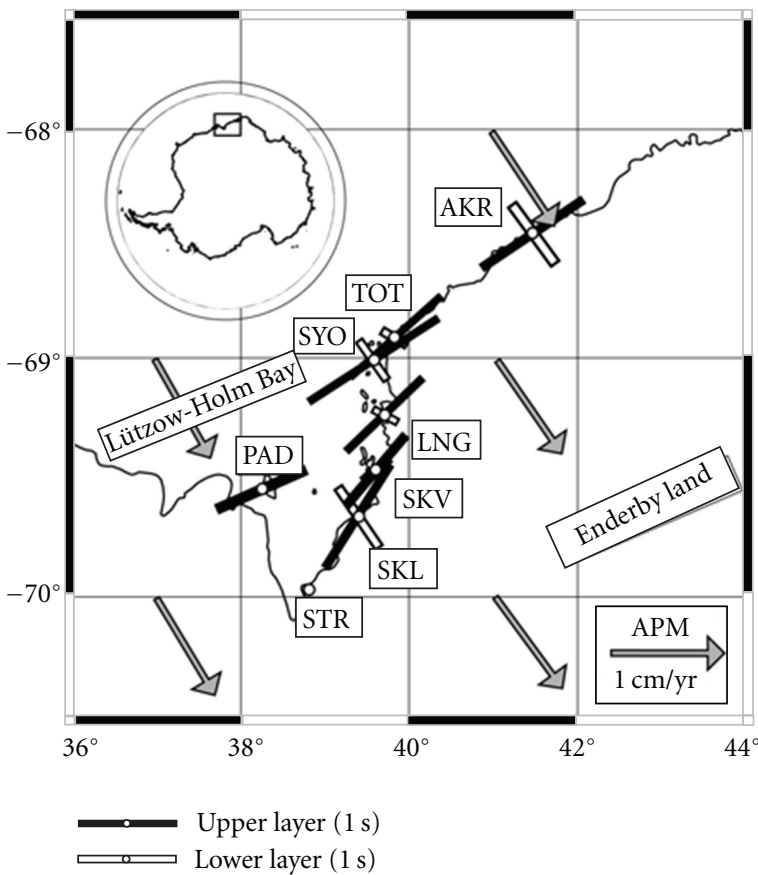

(a)

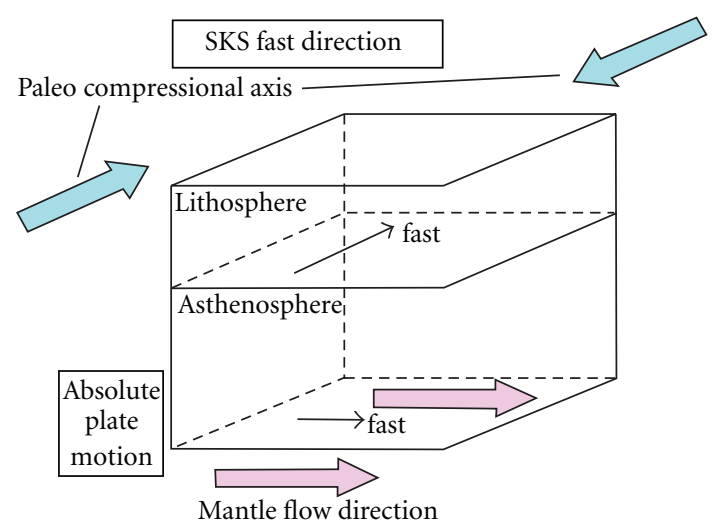

(b)

FIGURE 10: (a) Schematic illustration of the two-layered model for obtaining anisotropy. (b) Upper mantle anisotropy in LHB derived from SKS splitting (after Usui et al. 2007 [16]). At stations AKR, LNG, SKL, SYO, and TOT, the lower layer anisotropy was suspected to be caused by recent asthenospheric flow. For almost all other stations, the direction of the upper layer anisotropy (corresponds to the "lithosphere") was parallel to NE-SW convergence during the Pan-African age.

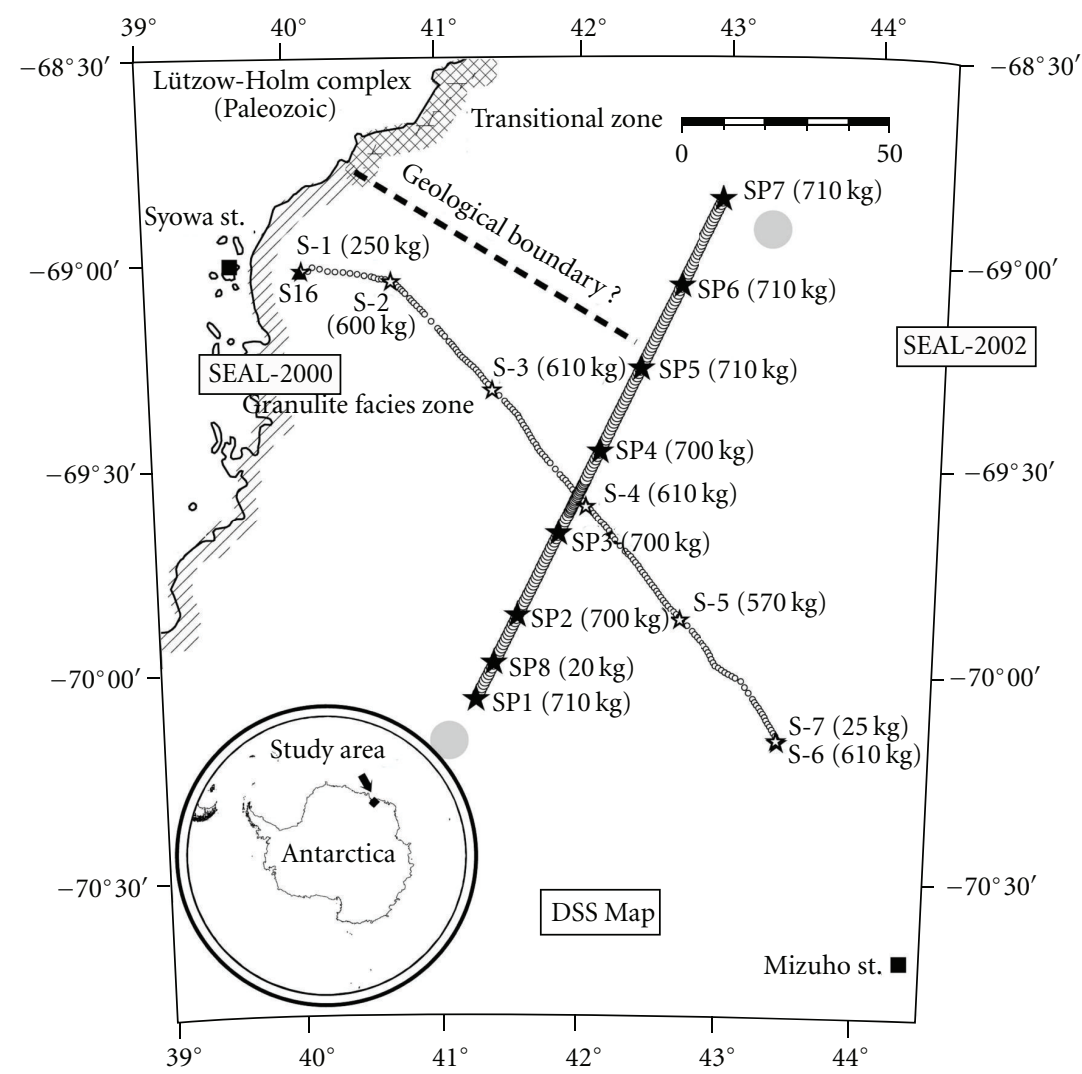

FIGURE 11: Map showing the location of DSS in LHB (after Kanao et al. 2010 [17]). Solid and open stars indicate the shot locations in SEAL-2002 and -2000, respectively. Large and small circles represent the geophone stations on ice sheet for both the DSS operations. The size of each shot given is weight of dynamite used. 

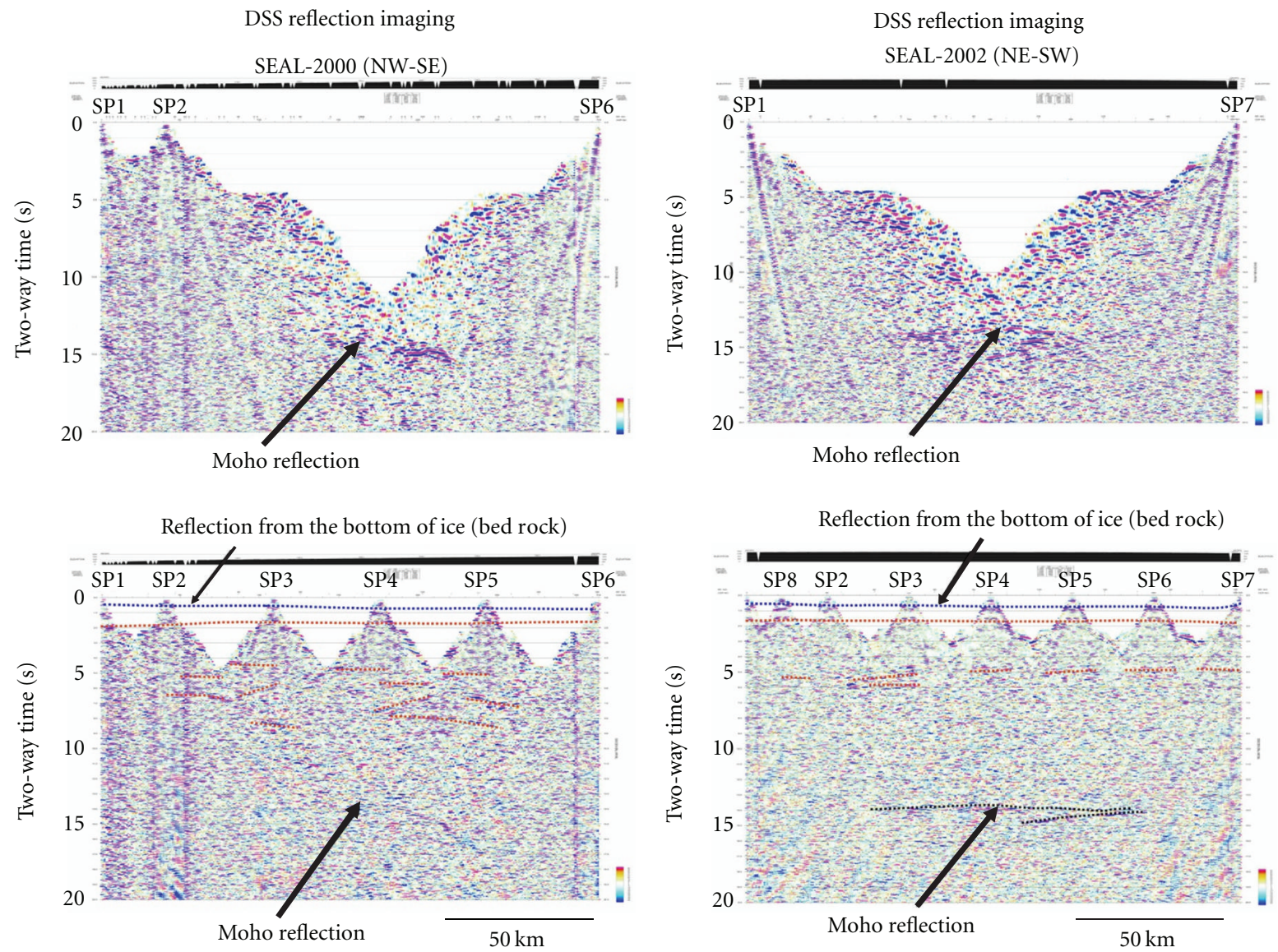

(a)

(b)

Figure 12: (a) (upper) Single-fold CDP section showing far offset shots for SP 1, SP 2, and SP 6 of the SEAL-2000 profile. The Moho reflections are indicated by black solid arrow. (lower) CDP stack section offset linked to near traces for the SEAL-2000 profile. Several reflections in the crust and the Moho are identified by red broken lines and black solid arrows, respectively. In addition, reflections from the bottom of the ice sheet are traced by the light-blue broken line. All the figures are after Kanao et al. [17]. (b) (upper) Single-fold CDP section showing far offset shots for SP 1 and SP 7 of the SEAL-2002 profile. The Moho reflections are indicated by black solid arrows. (lower) CDP stack section with offset limited to traces within $120 \mathrm{~km}$ for the SEAL-2002 profile. Several reflections in the crust and the Moho are identified by red- and black-colored broken lines. In addition, reflections from the bottom of the ice sheet are traced by the light-blue broken line. All the figures are after Kanao et al. [17].

Laminated layers of the lower crust in LHB, moreover, were numerically modeled by comparing synthetic receiver functions with those of observed waveforms in short period bands $(0.1-1.0 \mathrm{~Hz})$ [39]. The repetitive crust-mantle transition zone imaged by the SEAL-2002 profile suggests the presence of compression stress in an NE-SW orientation during the Pan-African age, in the last formation stage of a broad mobile belt between East and West Gondwana terrains. Successive break-up processes of Gondwana in the mid-Mesozoic could account for the formation of the stretched reflection structure around the Moho discontinuity as imaged on the SEAL-2000 profile (Figure 12(a)).

These seismic reflections were considered to represent multigenetic origins, including igneous intrusions, lithologic and metamorphic layering, mylonite zones, shear zones, seismic anisotropy, or fluid layers $[40,41]$. Though the cause of reflectivity may have a multigenetic origin, we suggest that metamorphic layering could be the principal cause in the case of LHB. A strong reflectivity in the deeper crust-upper mantle can be expected to result from layered sequences of mafic and felsic rocks [42]. In addition, such a reflectivity can be created where mafic rocks are interlayered with upper amphibolite and lower granulite facies metapelites [43].

In any continental terrains on Earth, the primary causes for reflectivity might be enhanced by ductile stretching during a late tectonic extensional process [44]. In particular, the reflecting layers near the Moho were predominantly found in crustally thinned tectonic areas. Accordingly, the reflectivity in the lower crust and lithospheric mantle beneath LHB might have been enhanced under extensional conditions caused by the last breakup of the Gondwana supercontinent. 


\section{Discussion}

In this section, a regional evolution model of LHB is presented to explain the formation process of the present structure as reviewed in the previous sections. A summary of evolution history, including major tectonic events in LHB, is demonstrated in Figure 14.

Geological studies by JARE revealed the regional metamorphism of LHB during the Pan-African orogeny [33]. Metamorphic grade increases progressively from amphibolite facies in the NE to granulite facies in the SW of LHB. The maximum thermal axis runs through the southern LHB with an NNW-SSE striking direction [29]. From geological evidence, the LHB terrain experienced deformation $r$ compression stress-oriented perpendicular to the thermal axis, almost parallel to the coast, during the last stage of the deformation process of a mobile belt located between the East- and West-Gondwana [32]. The high-amplitude magnetic anomalies occurring in LHB compared to those in the surrounding terrains ([45]; Figure 13) indicate the LHB may be located in one of the major suture zones of the PanAfrican mobile belt. This has been pointed out in recent studies in East Africa and in East Antarctica. These major suture zones appear to continue from LHB to the Shackleton Range of West Antarctica [32, 46].

The lower crust and upper mantle beneath LHB were characterized to have lateral and vertical variations as shown in seismological studies reviewed in this paper. The gently inland dipping Moho discontinuity (38-42 km) beneath the SEAL-2000 profile was inverted by travel-time analysis from refraction and wide-angle reflection surveys [18]. The present structure is attributed to hold the past regional tectonics, particularly metamorphic and orogenic activities in Pan-African age. Inferred thrust duplicated (similar to the wedge shaped) lower crust-upper mantle transition structures interpreted on the SEAL-2002 profile (Figure 12(b), [17]) also imply a compressive stress regime along the profile oriented in an NE-SW direction during the Pan-African. Through consideration with geophysical and lithologic information, LHB is considered to be formed under convergence, perpendicular to the thermal axis, during the collision between supraterrains of Gondwana during the last stage of supercontinent formation [39, 47]. If LHB underwent NE-SW compression, related paleo-mantle flow along this direction could produce the seismic anisotropy associated with the thermal axis of progressive metamorphism. Since the direction of paleo-compression is consistent with the resultant fast polarization by SKS splitting [16], anisotropy in the upper layer in Figure 9 can be explained by "lithospheric" deformation during the formation of LHB at Pan-African.

During the break-up between Antarctica and AustraliaIndia at $\sim 150 \mathrm{Ma}[48]$, the LHB experienced extensional stress, which caused thinning at the continental margins of East Antarctica. The flat lying reflectors above the crust-mantle boundary recognized in the SEAL-2000 profile (Figure 12(a)) suggest the presence of an extensional stress regime in the NW-SE direction resulting from break-up. The seismic reflective layers at the crust-mantle boundary and lithospheric mantle may have been enhanced by extensional conditions during the final stages of break-up. The Lattice Preferred Orientation (LPO) induced mechanical anisotropy developed along the direction of preexisting lithospheric structure during continental rifting [49]. The origin of anisotropy beneath Western Dronning Maud Land was pointed out as the ancient lithospheric structure modified by rifting processes during break-up [50]. As the spreading direction off the Enderby Land was NW-SE initial stage of break-up [51], a strike of the rift was generally parallel to the continental margin of LHB. The fast polarization directions of the upper layer ("lithosphere") in SKS analysis were roughly parallel to the continental margin. Therefore, it is plausible that break-up affected the formation of anisotropy in the lithosphere. The preexisting lithospheric structure might also influence the formation of anisotropy in succeeding break-up processes.

Finally, besides the studies for the crust and upper mantle, the recorded teleseismic waveforms have advantages to investigate the deep Earth's interiors such as the lower mantle, $\mathrm{D}^{\prime \prime}$ zones [15], Core-Mantle-Boundary (CMB), and the Inner Core $[14,52]$. The GARNET data in LHB can be utilized to study the deep Earth interior of the southern high latitudes. Further, these data can be combined with data from other projects in the region, such as AGAP/GAMSEIS and projects from collaborating nations in Antarctica. The broadband deployments in LHB offer effective contributions to GARNET, international Antarctic Array program, FDSN, POLENET, and the broader goals of the IPY and beyond.

\section{Conclusions}

Broadband seismic deployments around the Pan-African terrain of LHB, East Antarctica, provided clear images of characteristic structure of the upper mantle. Passive source studies using teleseismic events such as receiver functions and shear wave splitting demonstrated heterogeneous structure along the coast in the region. Depth variations of the upper mantle discontinuities $(410 \mathrm{~km}$ and $660 \mathrm{~km})$ were derived from long-period receiver functions recorded at LHB array stations. Shallow depths in topography of the upper mantle discontinuity particularly about $660 \mathrm{~km}$ depths were cleared beneath the continental ice sheet area where SE apart from the stations. These results may reflect paleo upwelling of the mantle plume associated with Gondwana break-up.

Lithospheric mantle anisotropy derived by SKS splitting anticipated relationship between "fossil" anisotropy and past tectonics. Fast polarization directions, mainly in NE-SW, were consistent with paleo compression during the PanAfrican. The origin of mantle anisotropy might be caused chiefly by LPO involving supercontinent assembly, rather than present asthenospheric flow parallel with Absolute Plate Motion. In addition, multidisciplinary lithospheric mantle images were combined by both active and passive sources conducted at LHB. DSS was carried out on the continental ice-sheet in 2000 and 2002 and provided clear information on the crust-mantle boundary, together with inner crustal and lithospheric mantle reflections. After processing of NMO 


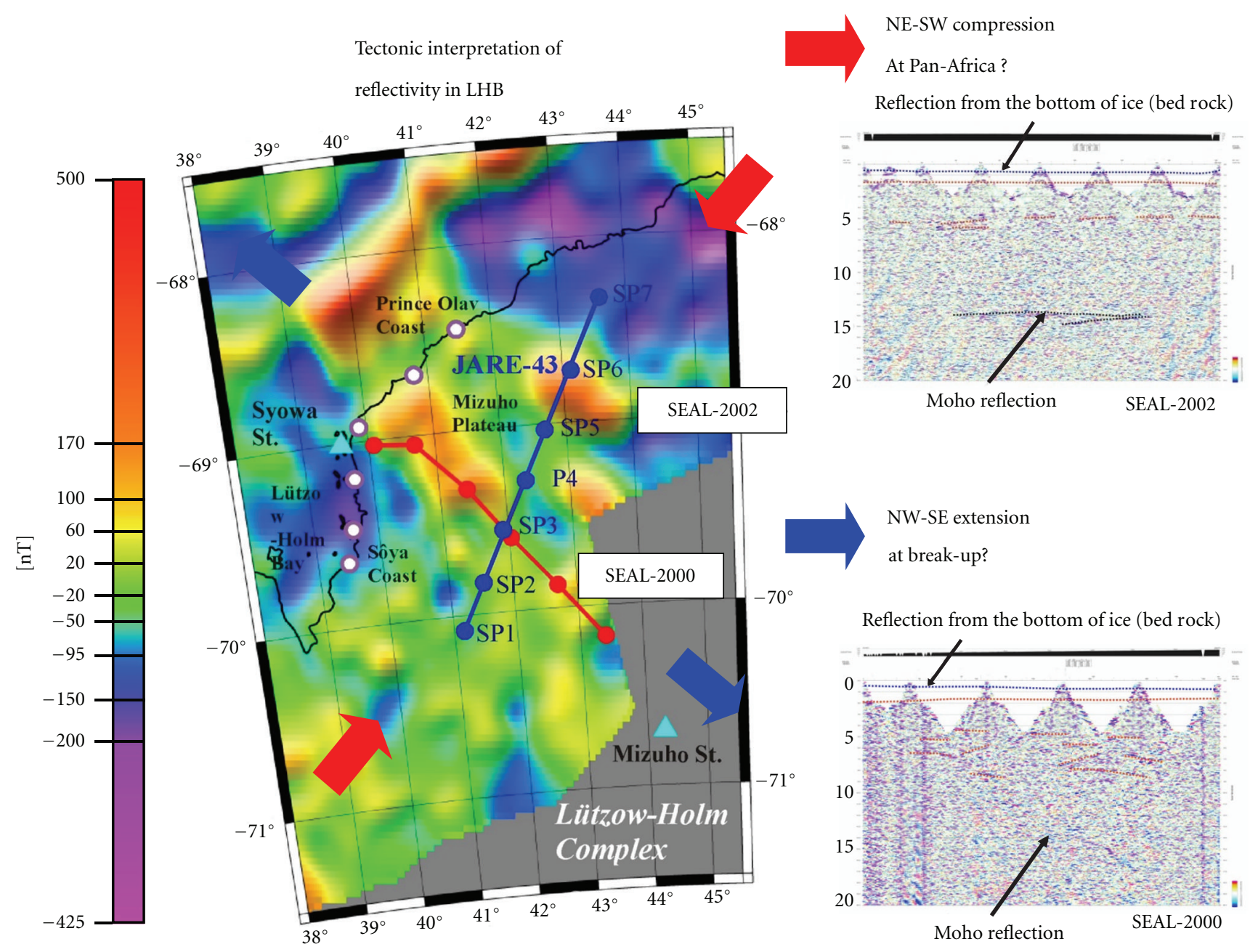

FIGURE 13: Aeromagnetic anomalies (by Golynsky et al., 1996 [18]) around LHB with GARNET stations and DSS profiles (modified after Kanao et al., 2010 [17]). Tectonic interpretation is illustrated with associated interpretations of reflection cross sections by DSS.

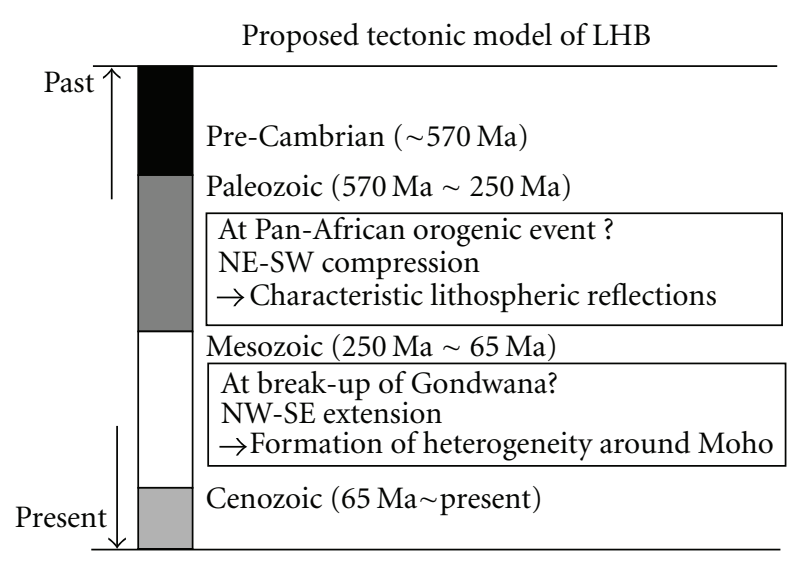

FIGURE 14: Summary of tectonic history proposed by seismological studies in LHB. Pan-African orogeny and Mid-Mesozoic break-up could be the major two events affecting the formation of the present upper mantle structure. 
corrections and CDP stacking, the DSS extracted lithospheric images imply tectonic influence of compressive stress during the Pan-African.

The broadband deployments in LHB, accordingly, could give rise to an effective contribution to regional and global seismic networks, international Antarctic Array programs, together with POLENET during IPY.

\section{Acknowledgments}

The authors would like to express their special appreciation to the participants of the JARE members for their great efforts to carry out the seismic array deployments around the LHB. The authors would like to express sincere thanks to Professors. K. Kaminuma, K. Shibuya, Y. Nogi, K. Doi, Y. Aoyama and the all staff of NIPR for their useful discussion about seismic deployments and upper mantle studies. They would like to thank the collaborators in the IPY projects for AGAP/GAMSEIS (Professor D. Wiens of Washington University, Professor A. Nyblade of Penn. State University, and others) and POLENET (Professor T. Wilson of the Ohio State University, Dr. S. Konfal, and others). They appreciate so much S. Konfal and T.Wilson for checking the paper and giving useful comments. The authors would like to express their sincere thankfulness for Professor J. Gamble of the Department of Geology, National University of Ireland, Professor A. K. Cooper of the Department of Geological and Environmental Sciences, Stanford University, and two anonymous referees of the special issue on "Seismic Imaging" in International Journal of Geophysics for their sincere and useful comments.

\section{References}

[1] M. Kanao, Y. Usui, T. Inoue et al., "Broadband seismic array deployments and Lithospheric structure around the LützowHolm Bay region, East Antarctica," in Antarctica: A Keystone in a Changing World. U. S. Geological Survey and The National Academies, A. K. Cooper, P. Barrett, H. Stagg et al., Eds., 2007, USGS OF-2007-1047, Extended Abstract 145.

[2] A. M. Reading, "Antarctic seismicity and neotectonics," in Antarctica at the Close of a Millennium, J. A. Gamble, Ed., vol. 35 of The Royal Society of New Zealand Bulletin, pp. 479-484, Wellington, 2002.

[3] G. Roult, D. Rouland, and J. P. Montagner, "Antarctica II: upper-mantle structure from velocities and anisotropy," Physics of the Earth and Planetary Interiors, vol. 84, no. 1-4, pp. 33-57, 1994.

[4] M. H. Ritzwoller, N. M. Shapiro, A. L. Levshin, and G. M. Leahy, "Crustal and upper mantle structure beneath Antarctica and surrounding oceans," Journal of Geophysical Research B, vol. 106, no. 12, pp. 30645-30670, 2001.

[5] R. Kobayashi and D. Zhao, "Rayleigh-wave group velocity distribution in the Antarctic region," Physics of the Earth and Planetary Interiors, vol. 141, no. 3, pp. 167-181, 2004.

[6] S. Bannister and B. L. N. Kennett, "Seismic activity in the Transantarctic Mountains - Results from a broadband array deployment," Terra Antarctica, vol. 9, no. 1, pp. 41-46, 2002.

[7] C. Müller and A. Eckstaller, "Local seismicity detected by the Neumayer seismological network, Dronning Maud Land,
Antarctica: tectonic earthquakes and ice-related seismic phenomena," in Proceedings of the 9th International Symposium on Antarctic Earth Sciences, Potsdam, Germany, 2003, Programme and Abstracts 236.

[8] A. M. Reading, "The SSCUA broadband seismic development, East Antarctica," in Proceedings of the 9th International Symposium on Antarctic Earth Sciences, 2003, Programme and Abstracts 270.

[9] D. Robertson, D. A. Wiens, and P. J. Shore, "Seismicity and tectonics of the South Shetland Islands and Bransfield Strait from the SEPA broadband seismograph deployment," in Antarctica at the Close of a Millennium, J. A. Gamble et al., Ed., vol. 35, pp. 549-554, The Royal Society of New Zealand Bulletin, Wellington, New Zealand, 2002.

[10] D. A. Wiens, S. Anandakrishnan, A. A. Nyblade et al., "Remote detection and monitoring of glacial slip from Whillans Ice Streeam using seismic rayleigh waves recorded by the TAMSEIS array," Eos, Transactions, American Geophysical Union,, vol. 87 , no. 52, 2006.

[11] J. F. Lawrence, D. A. Wiens, A. A. Nyblade, S. Anandakrishan, P. J. Shore, and D. Voigt, "Upper mantle thermal variations beneath the Transantarctic Mountains inferred from teleseismic S-wave attenuation," Geophysical Research Letters, vol. 33, no. 3, Article ID L03303, 2006.

[12] D. A. Wiens, "Broadband Seismology in Antarctica: recent progress and plans for the international polar year," in Proceedings of the International Symposium Asian Collaboration in International Polar Year National Committee, pp. 21-24, Tokyo, Japan, March 2007.

[13] S. E. Hansen, A. A. Nyblade, D. S. Heeszel, D. A. Wiens, P. Shore, and M. Kanao, "Crustal structure of the Gamburtsev Mountains, East Antarctica, from S-wave receiver functions and Rayleigh wave phase velocities," Earth and Planetary Science Letters, vol. 300, no. 3-4, pp. 395-401, 2010.

[14] T. Isse and I. Nakanishi, "Inner-core anisotropy beneath Australia and differential rotation," Geophysical Journal International, vol. 151, no. 1, pp. 255-263, 2002.

[15] Y. Usui, Y. Hiramatsu, M. Furumoto, and M. Kanao, "Evidence of seismic anisotropy and a lower temperature condition in the $\mathrm{D}^{\prime \prime}$ layer beneath Pacific Antarctic Ridge in the Antarctic Ocean," Physics of the Earth and Planetary Interiors, vol. 167, no. 3-4, pp. 205-216, 2008.

[16] Y. Usui, M. Kanao, and A. Kubo, "Upper mantle anisotropy from teleseismic SKS splitting beneath Lützow-Holm Bay region, East Antarctica," in Antarctica: A Keystone in a Changing World. U. S. Geological Survey and The National Academies, A. K. Cooper, P. Barrett, H. Stagg et al., Eds., 2007, SGS OF-2007-1047, Short Research Paper 013.

[17] M. Kanao, A. Fujiwara, H. Miyamachi et al., "Reflection imaging of the crust and the lithospheric mantle in the LützowHolm complex, Eastern Dronning Maud Land, Antarctica, derived from the SEAL transects," Tectonophysics, vol. 508, no. 1-4, pp. 73-84, 2011.

[18] A. V. Golynsky, V. N. Masolov, Y. Nogi et al., "Magnetic anomalies of Precambrian terrains of the East Antarctic shield coastal region (20E-50E)," Polar Geoscience, vol. 9, pp. 24-39, 1996.

[19] H. Negishi and M. Kanao, "Field seismic observations by portable broadband seismometers in the Lutzow-Holm Bay Region, East Antarctica," Antarctic Record, vol. 42, no. 2, pp. 179-189, 1998.

[20] M. Kanao and T. Higashi, "Geophysical research from field observations by the Earth Science Division in the 38th 
Japanese Antarctic Research Expedition (1996-1998)," Antarctic Record, vol. 43, no. 3, pp. 375-405, 1999.

[21] J. P. Winberry, "Stick-slip motion of antarctic ice streams: observations from the meter scale and the hundred-kilometer scale," in Proceedings of the International Workshop on Geophysics of Interior Antarctica, p. 20, Beijing, China, October 2010

[22] K. Kuge and Y. Fukao, "High-velocity lid of East Antarctica: evidence of a depleted continental lithosphere," Journal of Geophysical Research B, vol. 110, no. 6, pp. 1-15, 2005.

[23] K. Nawa, N. Suda, K. Satake et al., "Loading and gravitational effects of the 2004 Indian Ocean tsunami at Syowa Station, Antarctica," Bulletin of the Seismological Society of America, vol. 97, no. 1, pp. S271-S278, 2007.

[24] Y. Usui, Y. Hiramatsu, M. Furumoto, and M. Kanao, “Thick and anisotropic $\mathrm{D}^{\prime \prime}$ layer beneath Antarctic Ocean," Geophysical Research Letters, vol. 32, no. 13, pp. 1-4, 2005.

[25] M. Kanao and K. Kaminuma, "Seismic activity associated with surface environmental changes of the Earth system, around Syowa Station, East Antarctica," in Antarctica: Contributions to Global Earth Sciences, D. K. Futterer, D. Damaske, and G. Kleinschmidt, Eds., pp. 361-368, Springer, Berlin, Germany, 2006.

[26] A. Yamada, M. Kanao, and M. Yamashita, "Features of seismic waves recorded by seismic exploration in 2002: responses from valley structure of the bedrock beneath Mizuho Plateau," Polar Geoscience, vol. 17, pp. 139-155, 2004.

[27] M. Kanao, "Variations in the crustal structure of the LützowHolm Bay region, East Antarctica using shear wave velocity," Tectonophysics, vol. 270, no. 1-2, pp. 43-72, 1997.

[28] M. Kanao, A. Kubo, T. Shibutani et al., "Crustal structure around the Antarctic margin by teleseismic receiver function analyses," in Antarctica at the Close of a Millennium, J. A. Gamble, D. N. B. Skinner, and S. Henrys, Eds., vol. 35, pp. 485-491, Royal Society of New Zealand Bulletin, 2002.

[29] Y. Hiroi, K. Shiraishi, and Y. Motoyoshi, "Late Proterozoic paired metamorphic complexes in East Antarctica, with special reference to the tectonic significance of ultramafic rocks," in Geological Evolution of Antarctica, M. R. A. Thomson, J. A. Crame, and J. W. Thomson, Eds., pp. 83-87, 1991.

[30] L. P. Vinnik, L. I. Makeyeva, A. Milev, and A. Y. Usenko, "Global patterns of azimuthal anisotropy and deformations in the continental mantle," Geophysical Journal International, vol. 111, no. 3, pp. 433-447, 1992.

[31] A. E. Gripp and R. G. Gordon, "Young tracks of hotspots and current plate velocities," Geophysical Journal International, vol. 150, no. 2, pp. 321-361, 2002.

[32] I. C. W. Fitzsimons, "Grenville-age basement provinces in East Antarctica: evidence for three separate collisional orogens," Geology, vol. 28, no. 10, pp. 879-882, 2000.

[33] K. Shiraishi, D. J. Ellis, Y. Hiroi, C. M. Fanning, Y. Motoyoshi, and Y. Nakai, "Cambrian orogenic belt in East Antarctica and Sri Lanka: implications for Gondwana assembly," Journal of Geology, vol. 102, no. 1, pp. 47-65, 1994.

[34] Y. Motoyoshi, S. Matsubara, and H. Matsueda, "P-T evolution of the granulite facies rocks of the Lützow-Holm Bay region, East Antarctica, Evolution of Metamorphic Belts," in Geological Society Special Publication, J. S. Daly et al., Ed., vol. 43, pp. 325-329, 1989.

[35] H. Miyamachi, H. Murakami, T. Tsutsui et al., "A seismic refraction experiment in 2000 on the Mizuho Plateau, East Antarctica (JARE-41)—outline of observation," Antarctic Record, vol. 45, pp. 101-147, 2001 (Japanese).
[36] H. Miyamachi, S. Toda, T. Matsushima et al., "A seismic refraction and wide-angle reflection exploration in 2002 on the Mizuho Plateau, East Antarctica-outline of observations (JARE-43)," Antarctic Record, vol. 47, pp. 32-71, 2003 (Japanese).

[37] M. Kanao, M. Ishikawa, M. Yamashita, K. Kaminuma, and L. D. Brown, "Structure and evolution of the East Antarctic lithosphere: tectonic implications for the development and dispersal of Gondwana," Gondwana Research, vol. 7, no. 1, pp. 31-41, 2004.

[38] M. Yamashita, H. Miyamachi, M. Kanao et al., "Deep Reflection Imaging beneath the Mizuho Plateau, East Antarctica, by SEAL-2002 Seismic experiment," in Antarctica: Contributions to Global Earth Sciences, D. K. Futterer, D. Damaske, G. Kleinschmidt et al., Eds., pp. 147-154, Springer, Berlin, Germany, 2006.

[39] M. Kanao and M. Ishikawa, "Origins of the lower crustal reflectivity in the Lützow-Holm Complex, Enderby Land, East Antarctica," Earth, Planets and Space, vol. 56, no. 2, pp. 151$162,2004$.

[40] R. D. Hyndman and P. M. Shearer, "Water in the lower continental crust: modelling magnetotelluric and seismic reflection results," Geophysical Journal International, vol. 98, no. 2, pp. 343-365, 1989.

[41] S. B. Smithson and R. A. Johnson, "Crustal structure of the western U. S. based on reflection seismology: geophysical framework of the continental United States," Geological Society Special Publication, vol. 172, pp. 577-612, 1989.

[42] J. A. Goff, K. Holliger, and A. Levander, "Modal fields: a new method for characterization of random seismic velocity heterogeneity," Geophysical Research Letters, vol. 21, no. 6, pp. 493-496, 1994.

[43] L. Burlini and D. M. Fountain, "Seismic anisotropy of metapelites from the Ivrea-Verbano zone and Serie dei Laghi (northern Italy)," Physics of the Earth and Planetary Interiors, vol. 78, no. 3-4, pp. 301-317, 1993.

[44] M. Warner, "Basalts, water, or shear zones in the lower continental crust?” Tectonophysics, vol. 173, no. 1-4, pp. 163$174,1990$.

[45] L. A. Lawver and C. R. Scotese, "A revised reconstruction of Gondwanaland," in Gondwana Six: Structure, Tectonics and Geophysics, G. D. McKenzie, Ed., pp. 17-23, 1987.

[46] K. Yoshii, K. Ito, H. Miyamachi, and M. Kanao, "Crustal structure derived from refractions and wide-angle reflections in the Mizuho Plateau, East Antarctica," Polar Geoscience, vol. 17, pp. 112-138, 2004.

[47] M. Ishikawa and M. Kanao, "Structure and collision tectonics of Pan-African orogenic belt-scientific significance of the geotransect for a supercontinent: gondwanaland," Bulletin of Earthquake Research Institute, University of Tokyo, vol. 77, pp. 287-302, 2002 (Japanese).

[48] D. L. Anderson, "Superplumes or supercontinents?" Geology, vol. 22, no. 1, pp. 39-42, 1994.

[49] A. Tommasi and A. Vauchez, "Continental rifting parallel to ancient collisional belts: an effect of the mechanical anisotropy of the lithospheric mantle," Earth and Planetary Science Letters, vol. 185, no. 1-2, pp. 199-210, 2001.

[50] C. Müller, "Upper mantle seismic anisotropy beneath Antarctica and the Scotia Sea region," Geophysical Journal International, vol. 147, no. 1, pp. 105-122, 2001.

[51] Y. Nogi, N. Seama, N. Isezaki et al., "Magnetic anomaly lineations and fracture zones deduced from vector magnetic 
anomalies in the West Enderby Basin, in Weddell Sea Tectonics and Gondwana Break-up," in Geological Society Special Publication, B. C. Storey, E. C. King, and R. A. Livermore, Eds., vol. 108, pp. 265-273, 1996.

[52] X. Song and P. G. Richards, "Seismological evidence for differential rotation of the earth's inner core," Nature, vol. 382, no. 6588, pp. 221-224, 1996. 

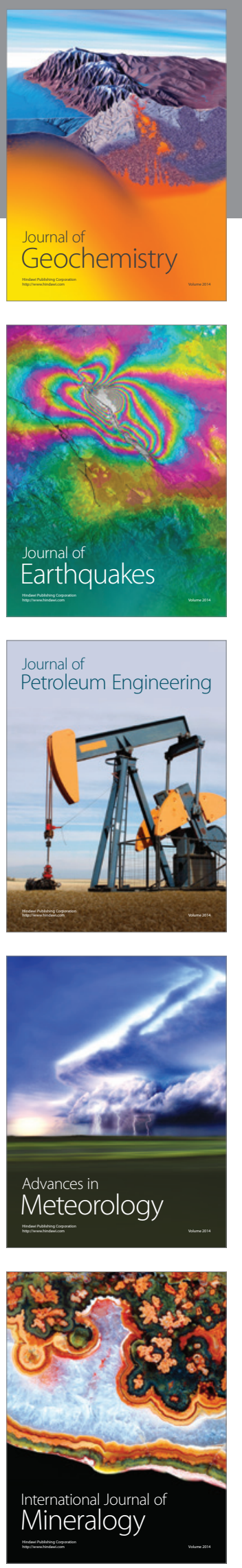
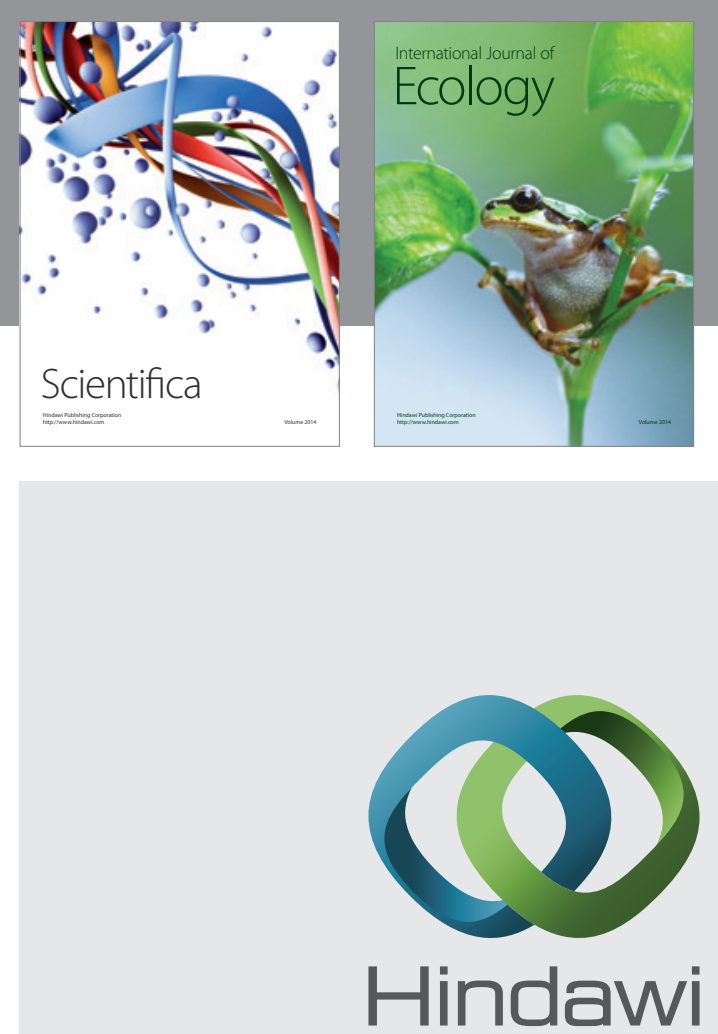

Submit your manuscripts at http://www.hindawi.com
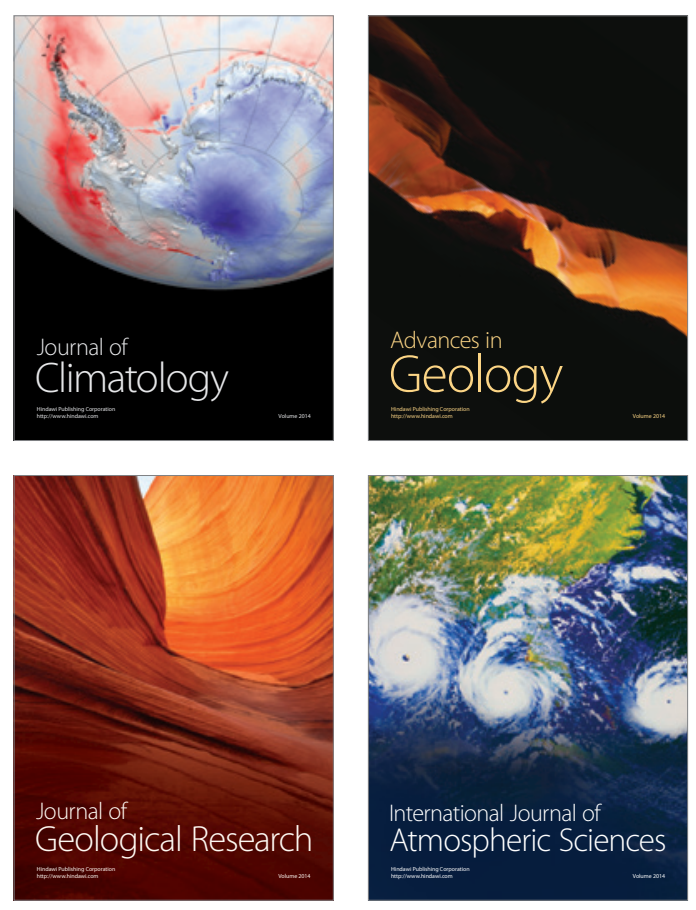
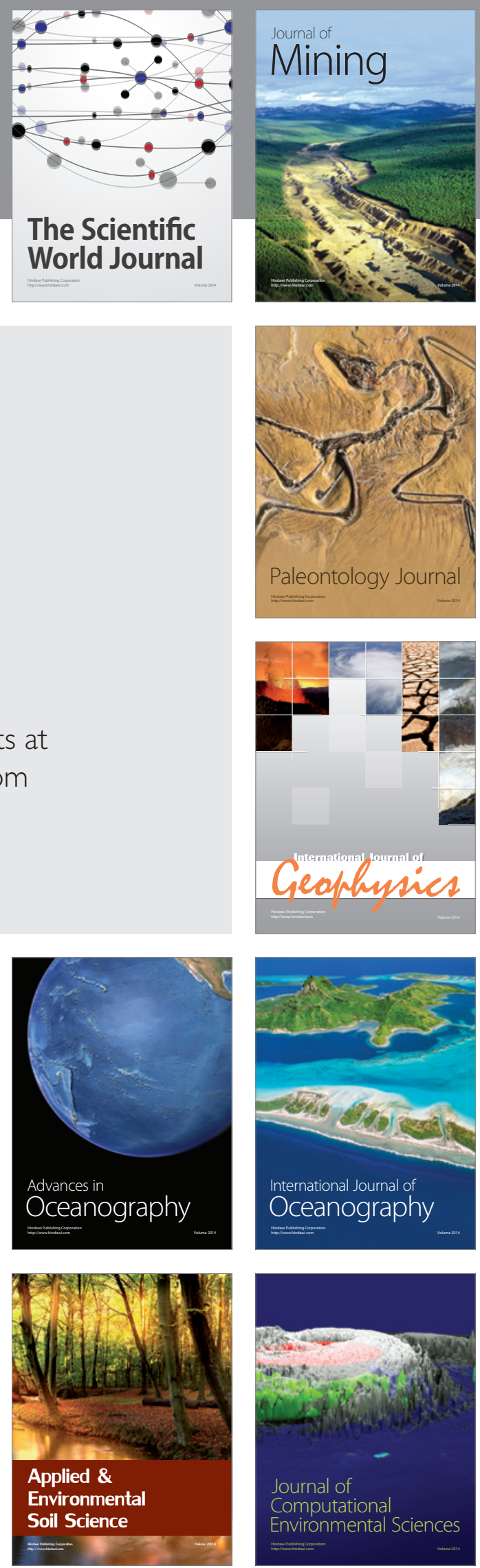